AGRICULTURE AND BIOLOGY JOURNAL OF NORTH AMERICA

ISSN Print: 2151-7517, ISSN Online: 2151-7525, doi:10.5251/abjna.2011.2.4.720.723

(C) 2010, ScienceHu, http://www.scihub.org/ABJNA

\title{
Performance of growing rabbits fed graded levels of bovine blood-rumen content mixture
}

\author{
Mohammed, G., Igwebuike, J.U and Alade, N.K. \\ Department of Animal Science, University of Maiduguri, P.M.B. 1069, Maiduguri, Nigeria
}

\begin{abstract}
A ten-week feeding trial was conducted to assess the growth and economic performance of growing rabbits fed bovine blood-rumen content mixture (BBRCM). The BBRCM which contained $35.4 \%$ crude protein and $25.10 \%$ crude fibre was included at $0,10,20,30$ and $40 \%$ levels in diets $1,2,3,4$ and 5 respectively to replace groundnut cake in the diets. Forty-five crossbred rabbits (Dutch X New Zealand White) between $5-7$ weeks of age were randomly allocated to the 5 treatments in group of 9 rabbits and allowed unlimited access to the feed and drinking water throughout the experimental period. The daily weight gain (DWG) which were10.77, 10.60, 11.10, 10.12 and $8.51 \mathrm{~g}$ for $T_{1}, T_{2}, T_{3}, T_{4}$ and $T_{5}$ respectively were not significantly $(p>0.05)$ different among the treatments. The corresponding daily feed intake of $56.10,62.67,67.09,71.57$ and 73.99gs were significantly $(P<0.05)$ different among the treatments. The feed cost per $\mathrm{kg}$ and feed cost per $\mathrm{kg}$ of weight gain decreased as the level of BBRCM increased in the diets. This lead to lowered feed cost and cost of production of rabbits. Therefore, $40 \%$ BBRCM could be incorporated into the diets of growing rabbits without adverse effects on performance.
\end{abstract}

\begin{abstract}
Keywords: Bovine blood-rumen content mixture INTRODUCTION

Rumen content (RC) is one of the abattoir byproducts that could be environmentally unfriendly if not properly handled. The rumen being the vat where fermentation of feed takes place contains various micro-organisms such as the phycomycetous fungi, protozoa, bacteria and others that are involved in this process (Preston, 1991; Mohammed et al., 2008). Investigations have revealed that rumen content and blood-rumen content mixture could serve as good sources of protein in monogastric diets (Mann, 1984; Dairo and Aina, 2000; Adenji and Balogun, 2002).
\end{abstract}

However, preliminary studies by Mohamed et al. (2008) indicated that differences exist between the rumen content of cattle, camel, sheep and goat with respect to nutrient composition, amino-acid profile and microbial assay. Therefore rumen content which is available in all abattoirs in Nigeria could be a good source of protein in livestock feed if properly processed and harnessed (Adeniji and Balogun, 2002). This study, therefore, investigated the performance of growing rabbits fed diets containing up to $40 \%$ bovine blood rumen content mixture (BBRCM) as replacement for groundnut cake.

\section{MATERIALS AND METHODS}

Study location: The study was conducted in Maiduguri which is located in the semi-arid area of growing rabbit, performance.

North Eastern Nigeria. The area is characterized by short raining season ( $3-4$ months) and very long dry season ( $8-9$ months). Mean ambient temperature is $31^{\circ} \mathrm{C}$ by August but gets as high as $40^{\circ} \mathrm{C}$ or more by April to May (Alaku and Moruppa, 1988).

Preparation of bovine blood-rumen content mixture: Bovine rumen content and blood were collected from the main abattoir in Maiduguri while slaughtering of the animals was in progress. The rumen was split open with the aid of a sharp knife and the content emptied into a 70 - litre plastic vat. A mixture of the material was made at a ratio of one part of blood and three parts of rumen content after which it was boiled in a drum with constant stirring. The boiling lasted for 30 minutes and this was done to reduce the microbial load of the mixture. The bovine blood-rumen content mixture (BBRCM) was sun-dried on a concrete floor to about $12 \%$ moisture and all the foreign objects were removed. After sundrying, the mixture was milled and store for mixing with other ingredients.

Management of the experimental stock: Forty-five (45) crossbred (Dutch $x$ New Zealand White) rabbits between 5 and 7 weeks of age were randomly allocated to five treatments in groups of 9 rabbits each. The rabbits were housed individually in cages measuring $35 \mathrm{~cm} \times 36 \mathrm{~cm} \times 45 \mathrm{~cm}$ (Width $\times$ Length $\mathrm{x}$ height) and supplied daily with the experimental diets in mash form. Clean drinking water was also 
provided ad libitum throughout the experimental period of 10 weeks.

Experimental diets: The experimental diets (Table 1) were compounded using maize, wheat offal, bovine blood-rumen content mixture, groundnut cake, groundnut haulms (hay), fish meal, salt and premix. The diets contained $0,10,20,30$ and $40 \%$ of bovine blood-rumen content mixture (BBRCM) in diets 1 (control) 2, 3, 4 and 5 respectively. The diets supplied approximately $19 \%$ crude protein.

Table 1: Composition of the experimental diets

\begin{tabular}{|l|c|c|c|c|c|}
\hline & \multicolumn{5}{|c|}{ Diets / Treatments } \\
\hline Ingredient (\%) & 1 & 2 & 3 & 4 & 5 \\
\hline Maize & 40.98 & 39.12 & 37.41 & 35.24 & 24.35 \\
\hline Wheat offal & 17.00 & 17.00 & 17.00 & 17.00 & 17.00 \\
\hline BBRCM & 0.00 & 10.00 & 20.00 & 30.00 & 40.00 \\
\hline Groundnut cake & 23.37 & 15.23 & 6.94 & 2.11 & 0.00 \\
\hline Fish meal & 3.00 & 3.00 & 3.00 & 3.00 & 3.00 \\
\hline Groundnut haulms & 13.00 & 13.00 & 13.00 & 13.00 & 13.00 \\
\hline Bone meal & 2.00 & 2.00 & 2.00 & 2.00 & 2.00 \\
\hline Common salt (Nacl) & 0.50 & 0.50 & 0.50 & 0.50 & 0.50 \\
\hline Premix* & 0.15 & 0.15 & 0.15 & 0.15 & 0.15 \\
\hline Total & 100.00 & 100.00 & 100.00 & 100.00 & 100.00 \\
\hline
\end{tabular}

BBRCM = Bovine blood-rumen content mixture

Premix (grow fast) manufacture by Animal care service consult (Nig) Ltd. Lagos, Suppling following per kg of premix. Vit. A, 5000,00 IU, Vitamin $D_{3} 800,000 I U$ vitamin E 12,000mg; vitamin K 1,5000mg, vitamin $B_{1}, 1,000 \mathrm{mg}$, vitamin $B_{2} 2,000 \mathrm{mg}$, vitamin $B_{6} 1,500 \mathrm{mg}$; Niancin 12,000mg; panlothenic acid 20.00mg; Biotin 10,000mg; vitamin $B_{12} 200.00 \mathrm{mg}$; folic acid 150,000mg; choline 60,000mg; manganese $10,000 \mathrm{mg}$; iron 15,000mg, zinc $800.00 \mathrm{mg}$. Copper 400.00mg; lodine $80.00 \mathrm{mg}$; cobalt 40mg; selenium 8,00mg.

Data collection: The daily feed intake was obtained by subtracting the left over from total amount of feed supplied. Each rabbit was weighed at the inception of the experiment and weekly thereafter to obtain the weekly and daily body weight gain throughout the experimental period. The feed conversion ratio was calculated as the dry matter feed intake per unit weight gain.

The economic implication of including BBRCM into the diets of growing rabbits was assessed by calculating the

i) Cost per kilogram of each diets

ii) Cost of feeding the rabbits on their respective diets throughout the experimental period and

iii) Cost per kilogram of weight gain by the rabbits

Chemical and statistical analysis: The proximate analysis of the experimental diets and BBRCM was carried out according to AOAC (1990) methods. Analysis of variance (ANOVA) was carried out on the data collected (Steel and Torrie, 1980) and mean separated, where applicable using the Duncan's Multiple Range test (Duncan, 1955).

\section{RESULTS AND DISCUSSION}

The nutrient composition of the experimental diets and bovine blood - rumen content mixture is presented in Table 2. The crude protein (CP) of the diets is similar and adequate for growing rabbits. This is in agreement with report of Mohammed et al (2005) who fed similar diets containing $18 \%$ CP to growing rabbits. However, the quality of dietary protein is very important in rabbit nutrition since voluntary feed intake has been found to increase with improvement in protein quality (Kennedy and Hersherger, 1974; Spreadbury, 1974). The crude fibre levels of the diets increased with increasing level of bovine blood-rumen content mixture (BBRCM) in the diets. This may be attributed to the higher fibre crude content of the BRRCM compared to groundnut cake (GNC). The fibre levels of the diets (18.34 to 22.00) were close to 15.0 to $20 \%$ recommended by Cheeke et al. (1982). Treatment 1 has the highest fat $(4.5 \%)$ while other treatment ranged from 2.0 to $3.90 \%$ which were comparable to the minimum requirement of $3 \%$ reported as the ideal level for rabbit (Cheeke, 1987). The lowest ash percentage was observed in treatment $1(2 \%)$ but values in other treatments were between 4.0 and $5.80 \%$. Nitrogen - free extract (NFE) values (52.17 $55.96 \%$ ) values were similar in all the treatments. 
The metabolizable energy levels of the diets were similar in T2, T3, T4, and T5 respectively, but higher value was recorded in T1 (3061.48 kcal $/ \mathrm{kg})$ ands this may be due to higher energy content of groundnut cake compared to bovine blood-rumen content mixture.

Table 2: Proximate composition of the experimental diets and bovine blood rumen-content mixture (on dry matter basis)

\begin{tabular}{|l|c|c|c|c|c|c|}
\hline & \multicolumn{5}{|c|}{ Treatments/Diets } \\
\hline Nutrients & $\mathrm{T}_{1}$ & $\mathrm{~T}_{2}$ & $\mathrm{~T}_{3}$ & $\mathrm{~T}_{4}$ & $\mathrm{~T}_{5}$ & $\mathrm{BBRCM}$ \\
\hline Dry matter & 91.10 & 91.10 & 90.70 & 91.40 & 91.80 & 90.82 \\
\hline Crude protein (CP) & 19.20 & 18.74 & 18.84 & 17.70 & 18.83 & 35.40 \\
\hline Crude fibre (CF) & 18.34 & 20.12 & 20.50 & 21.13 & 22.00 & 25.10 \\
\hline Ether extract (EE) & 4.50 & 2.50 & 2.00 & 2.50 & 2.50 & 3.90 \\
\hline Total Ash & 2.00 & 4.00 & 4.00 & 4.50 & 4.50 & 5.80 \\
\hline Nitrogen free extract (NFE) & 55.96 & 54.64 & 54.66 & 54.17 & 52.17 & 29.80 \\
\hline ME (Kcal/kg) & 3061.48 & 2800.10 & 2728.51 & 2815.94 & 2751.25 & 2683.60 \\
\hline
\end{tabular}

BBRCM = Bovine blood-rumen content mixture

$\mathrm{ME}=$ Metabolizable energy - calculated according to the formula of Pauzenga (1985), ME $=37 \times \% \mathrm{CP}+81 \times \% \mathrm{EE}+35.5 \times \% \mathrm{NFE}$

Performance characteristics: Results of performance parameters are presented in Table 3. Daily feed intake significantly $(P<0.05)$ increased as the inclusion levels of BBRCM increased in the diets. The daily feed intake $(56.20$ to $73.99 \mathrm{~g})$ reported were inferior to the values ( 72.55 to $81.04 \mathrm{~g} / \mathrm{rabbit} /$ day) recorded by Dairo (2005) who fed diets containing bovine-rumen content to growing rabbits. The difference observed may be due to different fibre levels of the diets. Chaudhury et al. (1995) revealed that rabbits given higher fibre ate more feed daily and gained more weight than rabbit on low fibre diets.

With respect to weight gain, all rabbits in the various treatment showed positive body weight gain, ranging from $8.51 \mathrm{~g}$ to $11.10 \mathrm{~g}$ rabbits / day although differences between the treatment means were not Table 3: Performance of Rabbits fed different levels of bovine blood-rumen content mixture (BBRCM)

\begin{tabular}{|c|c|c|c|c|c|c|}
\hline & \multicolumn{6}{|c|}{ Treatments/Diets } \\
\hline Nutrients & $\mathrm{T}_{1}$ & $\mathrm{~T}_{2}$ & $\mathrm{~T}_{3}$ & $\mathrm{~T}_{4}$ & $\mathrm{~T}_{5}$ & BBRCM \\
\hline Initial weight (g/rabbit) & 738.89 & 744.44 & 738.89 & 741.67 & 738.89 & $82.46^{\mathrm{NS}}$ \\
\hline Final live weight (g/rabbit) & $1408.3^{\mathrm{ab}}$ & $1422.20^{\mathrm{a}}$ & $1411.1^{\mathrm{a}}$ & $1425.00^{a}$ & $1244.4^{b}$ & $81.74^{*}$ \\
\hline Mean daily weight gain (g/rabbit) & 10.12 & 10.77 & 10.60 & 11.10 & 9.51 & $1.34^{\mathrm{NS}}$ \\
\hline Mean daily feed intake (g/rabbit) & $56.10^{\mathrm{C}}$ & $62.67^{b}$ & $67.09^{\mathrm{ab}}$ & $71.57^{\mathrm{a}}$ & $73.99^{b}$ & $2.27^{*}$ \\
\hline Feed conversion ratio (FCR) & 5.89 & $5.97^{\mathrm{C}}$ & $7.04^{\mathrm{bc}}$ & $8.54^{\mathrm{ab}}$ & $10.30^{\mathrm{a}}$ & 1.24 \\
\hline Mortality & 0 & 0 & 0 & 0 & 0 & 0 \\
\hline
\end{tabular}

SEM = Standard Error of Means

$a, b, c=$ Means in the row bearing different superscripts differ significantly $(P<0.05)$

NS $=$ Not significant $(P>0.05)$ statistically significant $(p<0.05)$. The values of daily weight gain reported in this study compared favorably with results obtained in similar studies (Egige, 1944; Dairo 2005; Mohammed et al 2005) in which graded levels of dried rumen content were incorporated into diets of young rabbits.

The feed conversion ratio which was computed as feed intake per unit weight gain differed significantly $(P<0.05)$. The highest feed conversion ratio of 10.30 was observed in treatment $5(40 \%$ BBRCM) while the lowest of 5.89 was observed in treatment $1(0 \%$ BBRCM). However the trend follows the same with that of daily feed intake, but the values obtained were higher than values recorded by Mohammed et al. (2005). 
Table 4: Economic performance of rabbit fed different levels of bovine blood-rumen content mixture (BBRCM)

\begin{tabular}{|c|c|c|c|c|c|}
\hline Parameters & \multicolumn{5}{|c|}{ Diets / Treatments } \\
\hline Levels of BBRCM & $\begin{array}{l}1 \\
0\end{array}$ & $\begin{array}{c}2 \\
10\end{array}$ & $\begin{array}{c}3 \\
20\end{array}$ & $\begin{array}{c}4 \\
30\end{array}$ & $\begin{array}{c}5 \\
40\end{array}$ \\
\hline Initial weight (g/rabbit) & 738.89 & 744.44 & 738.89 & 741.67 & 738.89 \\
\hline Final live weight (g/rabbit) & 1408.30 & 1422.20 & 1411.10 & 1425.00 & 1244.40 \\
\hline Total feed intake/rabbits (g) & 3534.30 & 3948.21 & 4226.67 & 4508.91 & 4031.37 \\
\hline Total feed intake / rabbit (kg) & 3.53 & 3.95 & 4.23 & 4.51 & 4.03 \\
\hline Cost/kg feed $(\mathrm{N})$ & 42.68 & 39.79 & 37.09 & 33.19 & 28.18 \\
\hline Total weight gain / rabbit (g) & 70.84 & 75.39 & 74.20 & 77.70 & 66.57 \\
\hline Total weight gain / rabbit $(\mathrm{kg})$ & 0.71 & 0.75 & 0.74 & 0.78 & 0.67 \\
\hline Cost /kg gain ( $\mathrm{A} / \mathrm{kg})$ & 212.20 & 209.56 & 212.01 & 191.92 & 169.50 \\
\hline
\end{tabular}

Cost per kilogram of the various ingredients used in compounding the experimental diets: Bovine blood - rumen content mixture, $\mathrm{A5.00}$;

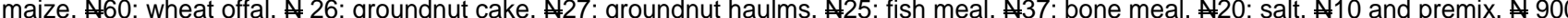

AOAC (1990). Official Methods of Analysis of Official Analytical; Chemists. $14^{\text {th }}$ ed. Association of Official Analytical; Chemists, Washington DC, USA.

Economic analysis: The economic performance presented in Table 4 showed that cost per kilogram of feed decreased steadily as the level of bovine blood-rumen content mixture (BBRCM) increased in the diets. This highest and lowest cost per feed were recorded in diets 1 (0\% BBRCM) and $5(40 \%$ BBRCM) respectively. The feed cost per $\mathrm{kg}$ of weight gain also steadily declined from $20 \%$ to $40 \%$ levels of bovine blood rumen content mixture (BBRCM) in the diets. Increasing the quantity of BBRCM in the diets resulted in the reduction of quantity of groundnut cake in the diets. Since ingredient is more expensive than bovine blood-rumen content mixture as shown in table 4. Thus, incorporated of BBRCM into the diets of growing rabbits lowered the feed cost and hence cost of production

\section{CONCLUSION}

The results revealed that up to $40 \%$ BBRCM could be incorporated into diets of growing rabbits without adverse effects on the performance of the rabbits. Additional advantages are reduced feed cost and lower cost per $\mathrm{kg}$ weight gain observed on the BBRCM - based diets. These are incentives that could warrant the recommendation of BBRCM as a dietary component for growing rabbits. However, further investigations will greatly assist in providing the necessary information on the effect of BBRCM on nutrient digestibility blood components and the histopathology of the digestive tract of growing rabbits.

\section{REFERENCES}

Adeniji, A. A and Balogun, O.O. (2000). Utilization of flavour treated Blood-rumen content mixture in the diets of laying hens. Nig. J. Anim. Prod. 29 (1): $34-39$.

Alaku, S.O. and Moruppa, S.M. (1988). Organ weight losses in goat during the long dry season in the Sahel Region of West Africa. J. Arid. Agric 1: 23 - 35.
Chaudhury, L.G. Singh, R; Kamra, D.N. and Pathack, D. (1995). Effect of oral administration of yeast on digestivity and growth performance of rabbit. Nutr Abstr. Rev. (series B) 3: $122-245$.

Dairo, F.A.S. and Aina, O.O. (2000). Ruminal content as a protein source in diet of growing rabbits. Proc. Of $25^{\text {th }}$ Ann. Conf. of Nig. Socio. For Animal Prod.. Okpara University of Agriculture, Umudike, 2000. pp $32-34$

Dairo, F.A.S; Aina, O.O. and Asafa, A.R. (2005). Performance evaluation of growing rabbits fed varying levels of rumen content and blood rumen content mixture. Nig. J. Anim. Prod. 32 (1): $67-72$.

Duncan, D.B. (1955). Multiple Range and Multiple F-test Biometrics 11: 1 - 42.

Egege, S.C. (1994). Rumen ingesta as feed supplement for rabbits sensory properties of meat from rabbits fed rumen ingesta. J. Agric. Technol. 2(2): 65 - 74.

Mann, I. (1984). High protein from blood and ruminal content using a solar drier World Anim. Rev. 50: 24 - 28.

Mohammed, G., Igwbuiike, J.U,. Kwari, I.D. (2005). Performance of growing rabbits fed graded levels of goat rumen content Global J. Pure and Appl. Sci 11(1): $39-$ 43.

Mohammed, G., Igwebuike J.U. Ubosi, C.O. and Alade, N.K. (2008). Comparative study of the nutrient composition, Amino acid profile and microbial Assay of fresh and dry cattle, camel, sheep, and goat, rumen contents. Proc. of the 13 Ann. Conf. of .Anim.sci.Assoc. of Nig. (ASAN) Sep 15-19, 2008. p-518-520

Preston, T.R. (1991). Matching ruminant production system with available resources in the tropics and sub-tropics CTA publication. A. J. Wageningen. The Metherlands pp. $21-30$.

Steel, R.G.D. and Torrie, J.H. (1980). Principles and procedure of statistics. A biometrical Approach. $2^{\text {nd }}$ ed. McGraw Hill Book. Co. New York, USA. P. 688. 